\title{
Analisis Penerapan SAK-ETAP (Standar Akuntansi Keuangan Entitas Tanpa Akuntabilitas Publik) Pada Penyajian Laporan Keuangan Koperasi Pegawai Republik Indonesia (KPRI) "Manfaat" LPMP Jawa Tengah \\ Mudjiyono \\ Yetti Iswahyuni \\ Akuntansi, STIE AKA Semarang, Indonesia
}

\section{Info Artikel}

Sejarah Artikel:

Diterima: 15 Juli 2019

Disetujui: 5 September 2019

Dipublikasikan: 1 Januari 2020

Keywords:

KPRI "Manfaat", Entity Financial Accounting Standards without Public Accountability (SAK_ETAP),

financial statements.
ABSTRAK

Koperasi Pegawai Repulik Indonesia (KPRI) "Manfaat" LPMP Jawa Tengah adalah merupakan badan usaha yang berbadan hukum Koperasi dan modalnya dimiliki oleh anggota-anggota yang melakukan sebagai pemakai jasa (users), Upaya yang dilakukan oleh suatu organisasi koperasi dalam mensejahterakan anggotanya tidak dapat lepas dari besarnya partisipasi yang diberikan anggota. sudah sepantasnya KPRI "Manfaat": ini mempertanggung jawabkan hasil kegiatan usahanya melalui penyajian laporan keuangan yang memadai dan sesuai standar akuntansi yang telah ditetapkan kepada para pemakainya.

Penelitian ini bertujuan menemukan dan menguji peraturan Standar Akuntansi Keuangan Entitas Tanpa Akuntabilitas Publik (SAK-ETAP) yang di tetapkan oleh Ikatan Akuntan Indonesia (IAI) dan yang di undangkan dalam peraturan Menteri Negara Koperasi dan Usaha Kecil dan Menegah Republik Indonesia No. 12/per/M.KUKM/IX/2015 tentang Pedoman Akuntansi Koperasi yang diterapkan secara faktual pada KPRI "Manfaat" LPMP Jawa Tengah

Jenis dan Desain Penelitian ini adalah penelitian diskriptif kualitatif yaitu jenis penelitian yang dengan menggunakan data primer berupa dokumen laporan keuangan dan wawancara dengan pengurus KPRI "Manfaat" dan pihak dari Dinas Koperasi dan Usaha Mikro, Kecil dan Menengah Kota Semarang. Guna mendadatkan informasi lebih dalam tentang kebijakan yang digunakan dalam penyusunan laporan keuangan.

Hasil dari penelitian in, peneliti menarik kesimpulan bahwa pencatatan pembukuan keuangan KPRI "Manfaat" LPMP Jawa Tengah secara umumnya sudah cukup baik namun belum mererapkan peraturan SAK-ETAP yang ditetapkan oleh IAI dan belum menjalankan aturan perundangan sesuai dengan Peraturan Menteri Negara Koperasi dan Usaha Kecil dan Menengah Republik Indonesia No.12/per/M.KUKM/IX/2015.

Kata kunci: KPRI "Manfaat", Standar Akuntansi Keuangan Entitas Tanpa Akuntabilitas Publik (SAK_ETAP), Laporan keuangan,, 
JBE Vol 5, No. 1, Januari 2020, pp: 15 - 27

\section{ABSTRACT}

Indonesian Repulik Cooperative Employees (KPRI) "Manfaat" Central Java LPMP is a business entity that is a legal entity and its capital is owned by members who perform as service users (users), Efforts made by a cooperative organization in the welfare of its members cannot be separated from the amount of participation given by members. It is appropriate that KPRI "Manfaat": this is responsible for the results of its business activities through the presentation of adequate financial statements and in accordance with predetermined accounting standards. To the users.

This study aims to find and test the rules of the Entity without Public Accountability (SAKETAP) Financial Accounting Standards set by the Indonesian Institute of Accountants (IAI) and which is enacted in the regulation of the Minister of Cooperatives and Small and Medium Enterprises of the Republic of Indonesia No. 12 / per / M.KUKM / IX / 2015 concerning Cooperative Accounting Guidelines that are applied factually to KPRI "Manfaat" of Central Java LPMP

Type and Design This research is a qualitative descriptive study, namely the type of research that uses primary data in the form of financial report documents and interviews with management KPRI "Manfaat" and parties from the Cooperative and Micro, Small and Medium Enterprises of Semarang City. In order to make deeper information about the policies used in the preparation of financial statements.

The results of this study, the researchers draw the conclusion that recording the financial bookkeeping of KPRI "Manfaat" of the Central Java LPMP has generally been good enough but has not applied the SAK-ETAP regulations stipulated by IAI and has not implemented legislation in accordance with the Regulation of the Minister of State for Cooperatives and Small Businesses and Menengah Republik Indonesia No.12 / per / M.KUKM / IX / 2015.

Keywords: KPRI "Manfaat", Entity Financial Accounting Standards without Public Accountability (SAK_ETAP), financial statements.

Jl Citarum no 44 Semarang 


\section{A. PENDAHULUAN.}

\section{Latar Belakang Masalah}

Koperasi adalah badan usaha yang mengorganisir pemanfaatan dan pendayagunaan sumber daya ekonomi para anggotanya atas dasar prinsip-prinsip koperasi dan kaidah usaha ekonomi untuk meningkatkan taraf hidup anggota pada khususnya dan masyarakat pada umunya, dengan demikian koperasi merupakan gerakkan ekonomi rakyat dan sokoguru perekonomian nasional.

Upaya yang dilakukan oleh suatu organisasi usaha khususnya Koperasi dalam mensejahterakan anggotanya tidak dapat lepas dari besarnya partisipasi yang diberikan anggota. Keaktifan seorang anggota dapat diwujudkan antara lain dengan bersedianya secara pribadi menjadi pengurus atau pengawas koperasi yang harus memiliki akuntabilitas yang baik. Pengertian akuntabilitas adalah sebagai suatu kemampuan mempertanggung jawabkan atas tugas-tugas yang telah dijalankan terhadap pihakpihak yang seharusnya atau patut menerima pertanggungjawaban.

Anggota koperasi yang merupakan pemilik mutlak suatu organisasi koperasi harus mendapatkan informasi tentang keberadan koperasi yang dapat dilihat dalam laporan pengurus yang berisikan tentang laporan keuangan ataupun laporan tentang kegiatan usaha koperasi yang biasanya diberikan kepada para anggota dalam setiap Rapat Anggota. Suatu badan usaha dalam proses organisasinya harus memiliki catatan yang berhubungan dengan keuangan ataupun non keuangan secara terinci dan dapat dipertanggungjawabkan, yang dalam organisasi koperasi, pertanggungjawaban itu harus dilakukan kepada seluruh anggota yang biasanya dilakukan dalam kurun waktu satu tahun satu kali dalam rapat anggota tahunan (RAT).

Laporan keuangan dalam suatu organisasi sangatlah penting dalam menunjang kinerja suatu organisasi, karena dengan laporan keuangan dapat dilihat bagaimana kinerja organisasi tersebut dalam mencapai tujuannya. Dengan meningkatnya arus sekonomi global, kualitas informasi dalam laporan keuangan harus dapat ditingkatkan agar informasi yang terdapat pada laporan keuangan tersebut dapat dijadikan landasan dalam menggambil keputusan. Namun sebagaimana kita ketahui bahwa lembaga usaha khususnya koperasi dalam menyajikan laporan keuangan masih banyak yang belum bisa menerapkan laporan keuangan yang berdasar pada standar akuntansi keuangan sebagaimana yang diharapkan oleh bank guna membantu permodalan koperasin

Terkait dengan kondisi tersebut, maka pada tanggal 17 Juli 2009 IAI (Ikatan Akuntan Indonesia) melalui DSAK (Dewan Standar Akuntansi Keuangan) menetapkan SAK ETAP (Standar Akuntansi Keuangan Entitas Tanpa Akuntabilitas Publik) sebagai standar yang dapat menjadi panduan entitas tanpa akuntabilitas publik dalam melakukan pembukuan akuntansi untuk menghasilkan laporan keuangan yang sesuai dengan standar. Standar yang resmi diberlakukan efektif sejak 1 Januari 2011 silam ini diharapkan dapat membantu pengusaha Koperasi UMKM dalam menerbitkan laporan keuangan yang lebih informatif dengan tujuan memberikan kemudahan bagi pihak investor dan kreditor untuk memberikan bantuan pembiayaan, disamping untuk membantu pemilik mengetahui kondisi keuangan usahanya serta sebagai pelengkap persyaratan ketika akan mengajukan kredit ke Bank atau lembaga keuangan lainnya.

Adapun obyek penelitian ini adalah Koperasi Pegawai Republik Indonesia (KPRI) "Manfaat" LPMP Jawa Tengah yang berlokasi di Jalan Kyai Mojo Kelurahan Srondol Kulon Kecamatan Banyumanik Kota Semarang. Yang bergerak dibidang simpan pinjam pegawai dan pertokoan. Meskipun sejak tahun 2014 usaha ini sudah menggunakan sistem komputerisasi, namun pencatatan keuangan yang dilakukan pemilik perusahaan masih secara manual dan hanya mencatat pendapatan dan pengeluaran perusahaan secara sederhana saja.

Penulis menganggap perlu untuk mengkaji masalah yang timbul dikalangan usaha perkoperasian berkaitan dengan penyusunan laporan keuangan. Laporan keuangan seharusnya menjadi kebutuhan bagi setiap unit usaha, terutama bagi badan usaha koperasi, mengingat manfaat yang dapat diperoleh bagi keberlanjutan usaha itu sendiri.

Melihat fenomena masih banyaknya badan usaha yang belum bisa menyusun laporan keuangan yang sesuai standar, maka peneliti tertarik membuat penelitian dengan judul "Analisi Penerapan SAK-ETAP (Standar Akuntansi Keuangan Entitas Tanpa Akuntabilitas Publik) Pada Penyajian Laporan Keuangan Koperasi Pegawai Republik Indonesia (KPRI) "Manfaat" LPMP Jawa Tengah" 


\section{a. Batasan Masalah}

Untuk menghindari penelitian yang terlalu luas, maka peneliti membatasi dan memfokuskan peneltian ini tentang penerapan SAK-ETAP pada Koperasi Simpan Pinjam (KSP) dan kendala-kendala yang dihadapi oleh KSP KPRI "Manfaat" LPMP Jawa Tengah.

\section{b. Rumusan Masalah}

Berdasarkan latar belakang di atas, maka rumusan masalah yang akan dibahas dan dicari solusinya dalam penelitian ini adalah:

a) Apakah penyusunan laporan keuangan koperasi KPRI "Manfaat LPMP Jawa Tengah sesuai dengan SAK ETAP?

b) Apa saja kendala yang dihadapi perusahaan dalam penerapan SAK ETAP?

\section{c) Tujuan Penelitian}

Sesuai dengan perumusan masalah tersebut diatas, maka yang menjadi tujuan dilakukannya penelitian ini yakni:

1. Untuk mengimplementasikan cara penyusunan laporan keuangan yang sesuai dengan Standar Akuntansi Keuangan untuk Entitas Tanpa Akuntabilitas Publik (SAK ETAP) pada KPRI Manfaat LPMP Jawa Tengah..

2. Untuk mengetahui kendala apa saja yang dihadapi oleh lembaga koperasi ini dalam penyusunan laporan keuangan berbasis SAK ETAP.

3.

\section{B. Kajian Pustaka}

\section{Koperasi}

Menurut Undang-undang No 25 Tahun 1992 Tentang Perkoperasian Indonesia. Koperasi adalah Badan Usaha yang beranggotakan orang-orang atau badan hukum koperasi dengan melandaskan kegiatannya berdasarkan prinsip koperasi sekaligus sebagai gerarakan gerakan ekonomi rakyat yang berdasarkan azas kekeluargaan.

Tugas Pemerintah dalam membangun dan mengembangkan koperasi sebagai badan usaha sekaligus sebagai gerakan ekonomi rakyat adalah untuk mewujudkan koperasi yang dikelola secara profesional dengan menerapkan prinsip keterbukaan, transparansi dan akuntabilitas yang dapat diakui, diterima dan dipercaya, baik oleh anggota pada khususnya maupun oleh masyarakat luas pada umumnya.
Salah satu indikator terlaksananya penerapan prinsip tersebut adalah melalui penyelenggaraan akuntansi secara benar dan tertib. Oleh karena koperasi harus memiliki identitas, maka penerapan akuntansi dan penyampaian laporan keuangannya juga menunjukkan kekhususan dibanding dengan akuntansi dan laporan keuangan badan usaha lain pada umumnya.Laporan keuangan koperasi menyajikan informasi yang menyangkut kondisi, kinerja dan perubahan posisi keuangan koperasi, yang bermanfaat bagi pengambilan keputusan strategis untuk pengembangan koperasi dimasa yang akan datang..

Pedoman ini merupakan penyempurnaan atas Pedoman Umum Akuntansi Koperasi Indonesia sebelumnya, yang berisi praktek penerapan akuntansi pada koperasi dengan memperhatikan perubahan pada perkembangan Standar Akuntansi Keuangan yang mengacu pada laporan keuangan internasional (International Financial Reporting Standard atau IFRS). Dewan Standar Akuntansi Keuangan, Ikatan Akuntan Indonesia pada tanggal 8 April 2011 telah menerbitkan Pernyataan Pencabutan Standar Akuntansi Keuangan 8 (PPSAK 8) atas pencabutan Pernyatan Standar Akuntansi Keuangan 27 (PSAK 27) mengenai Akuntansi Koperasi.

Standar Akuntansi keuangan yang mengacu pada IFRS (International Financial Report Standard) dikelompokkan menjadi 2 (dua) yaitu Standar Akuntansi Keuangan Entitas Tanpa Akuntabilitas Publik (SAK ETAP) dan Standar Akuntansi Keuangan Umum (SAK Umum).

Mengingat koperasi sejauh ini termasuk dalam entitas tanpa akuntabilitas publik, maka memberlakukan akuntansi koperasi dengan SAK ETAP dan SAK-ETAP ini diadobsi dan diundangkan dalam Peraturan Menteri Koperasi Dan Usaha Kecil dan Menengah Republik Indonesia Tentang Pedoman Umum Akuntansi Koperasi Sektor Riil. Pedoman ini menetapkan bentuk, isi penyajian dan pengungkapan laporan keuangan koperasi untuk kepentingan internal koperasi maupun pihak lain selaku pengguna laporan keuangan koperasi. Pedoman ini merupakan acuan yang harus dipatuhi oleh koperasi dan aparat dalam melakukan pembinaan dalam menyusun laporan keuangan.

\section{a. Maksud dan Tujuan}

Maksud dan Tujuan Pedoman Umum Akuntansi Koperasi adalah untuk menyediakan pedoman yang standar tentang penyajian laporan keuangan koperasi, sehingga membantu mempercepat pengurus dalam menyusun laporan pertanggungjawaban keuangan koperasi pada rapat anggota tahunan, maupun untuk tujuan-tujuan lain. 


\section{b. Sasaran}

Sasaran Pedoman Umum Akuntansi Koperasi adalah untuk:

1. Memberikan infomasi keuangan yang membantu para laporan dalam pengambilan keputusan dan menetapkan investasipada koperasi;

2. Memberikan informasi mengenai perubahan aset, kewajiban dan ekuitas koperasi secara nyata;

3. Memberikan informasi bahwa pengelolaan usaha koperasi sesuai dengan tata nilai, jatidiri koperasi;

4. Mengungkapkan informasi yang berhubungan dengan laporan keuangan yang relevan untuk kebutuhan pemakai laporan.

\section{c. Ruang Lingkup}

Pedoman umum akuntansi koperasi ini mengatur informasi keuangan koperasi yang disajikan dalam neraca, perhitungan hasil usaha, catatan atas laporan keuangan, laporan arus kas, laporan perubahan ekuitas dan catatan atas laporan keuangan.

\section{Akuntabilitas Keuangan}

Akuntabilitas Keuangan Koperasi adalah merupakan pertanggungjawaban pimpinan yang telah ditunjuk dan ditetapkan oleh dan dalam Rapat Umum Pemegang Saham (RAT) dalam pengelolaan kopersasi selama satu periode yang telah dtetapkan dan biasanya selama satu tahun.Pemeriksaan yang dapat dilakukan dalam organisasi koperasi terbagi menjadi dua, yaitu pemeriksaan formal dan pemeriksaan material (Munkner,1997). Perbedaan jenis-jenis pemeriksaan keuangan yang dilakukan oleh seorang pemeriksa yakni:

1. Pemeriksaan Keuangan Formal, yaitu pemeriksaan yang berkenaan dengan ketetapan matematis hasil pengelolaan manajemen yang diperlihatkan dalam neraca keuangan.

2. Pemeriksaan Material, yaitu pemeriksaan yang berkenaan dengan penilaian yang objektif tentang kualitas pengelolaan manajemen selama periode tertentu.

Terhadap laporan keuangan koperasi yang digolongkan kedalam pemeriksaan formal hukum yang berlaku, yaitu Pernyataan Standar Akuntansi No. 27 (Revisi 1988) Tentang Akuntansi Perkoperasian yang dikeluarkan oleh Ikatan Akuntansi Indonesia Per 1 Oktober 2004 dari halaman 27.1 sampai dengan 27.18 yang merupakan panduan proses pencatatan keuangan, yang dimulai dari adanya transaksi sampai menghasilkan laporan keuangan yang berlaku umum. Sedangkan pelaksanaan pemeriksaannya, baik yang dilakukan oleh internal audit ataupun eksternal audit, harus berdasarkan Pernyataan Standar Auditing (PSA) No. 02 sampai dengan PSA No. 58 yang dikeluarkan oleh Ikatan Akuntan Indonesia Per 1 Agustus 1994 yang berisikan tentang aturan-aturan pengauditan yang telah berlaku umum.

Transparansi adalah memberikan informasi keuangan yang terbuka dan jujur kepada masyarakat berdasarkan pertimbangan bahwa masyarakat memiliki hak untuk mengetahui secara terbuka dan menyeluruh atas pertanggungjawaban pemerintah dalam pengelolaan sumber daya yang dipercayakan kepadanya dan ketaatannya pada peraturan perundang- undangan $(\mathrm{KK}$, SAP, 2005).

a. Kriteria Akuntabilitas keuangan adalah sebagai berikut

1) Pertanggungjawaban dana publik

2) Penyajian tepat waktu

3) Adanya pemeriksaan (audit) /respon pemerintah.

Penyelengaraan pemerintahan yang transparan akan memiliki kriteria sebagai berikut.

1. Adanya pertanggungjawaban terbuka;

2. Adanya aksesibilitas terhadap laporan keuangan;

3. Adanya publikasi laporan keuangan, hak untuk tahu hasil audit dan ketersediaan informasi kinerja.

Jika dilihat dari definisi dan criteria di atas, tidak ada ktiteria yang jelas mengenai seperti apa bentuk laporan keuangan itu sehingga sebuah laporan keuangan dapat disebut sebagai laporan keuangan yang transparan dan akuntabel. Definisi dan criteria di atas hanya mencakup akuntabilitas dan transparansi dalam pengelolaan keuangan, bukan laporan keuangan.

Dalam ranah keuangan publik, UU no 17 tahun 2003 menuntut adanya transparansi dan akuntabilitas dalam keuangan publik. Laporan keuangan memang merupakan salah satu hasil dari transparansi dan akuntabilitas keuangan public. Dan ini berarti laporan keuangan yang disusun pun harus memenuhi syarat akuntabilitas dan transparansi. Namun, hingga saat ini belum ada criteria normative mengenai transparansi dan akuntabilitas laporan keuangan. Bahkan dalam PSAP pun belum disebutkan criteria laporan keuangan yang akuntabel dan transparan. 
Hal ini berbeda jika dibandingkan dengan kriteria laporan yang relevan dan andal. Dalam PSAK no 1, laporan keuangan disebut relevan jika berguna bagi pengguna informasi untuk mengambil keputusan. Sedangkan laporan keuangan disebut andal jika dapat mememenuhi syarat sebagai berikut.

1. Mencerminkan kejujuran penyajian hasil dan posisi keuangan perusahaan.

2. Menggambarkan substansi ekonomi dari sesuatu kejadian atau transaksi dan tidak semata-mata bentuk hukumnya.

3. Netral, yaitu bebas dari keberpihakan.

4. Mencerminka kehati-hatian.

5. Mencakup semua hal yang material

Jadi, jelas jika sebuah laporan keuangan memenuhi syarat tersebut, maka laporan keuangan dapat dikatakan relevan dan andal.

\section{Definisi dan Komponen Laporan Keuangan}

Pengertian laporan keuangan menurut Ikatan Akuntan Indonesia sebagaimana tercantum dalam Standar Akuntansi Keuangan No. 1 (IAI, 2009:5), adalah suatu penyajian terstruktur dari posisi keuangan dan kinerja keuangan suatu entitas. Tujuan laporan keuangan adalah memberikan informasi mengenai posisi keuangan, kinerja keuangan, dan arus kas entitas yang bermanfaat bagi sebagian besar kalangan pengguna laporan dalam pembuatan keputusan ekonomi. Laporan keuangan juga menunjukkan hasil pertanggungjawaban manajemen atas penggunaan sumber daya yang dipercayakan kepada mereka. Dalam rangka mencapai tujuan tersebut, laporan keuangan menyajikan informasi mengenai entitas yang meliputi: aset, liabilitas, ekuitas, pendapatan dan beban termasuk keuntungan dan kerugian, kontribusi dari dan distribusi kepada pemilik dalam kapasitasnya sebagai pemilik dan arus kas.

Sedangkan menurut Harahap (2007:121), pengertian laporan keuangan adalah output dan hasil akhir dari proses akuntansi atau laporan keuangan inilah yang menjadi bahan informasi bagi para pemakainya sebagai salah satu bahan dalam proses pengambilan keputusan. Disamping sebagai informasi bagi para pemakai, laporan keuangan juga sebagai bentuk pertanggungjawaban atau accountability pemilik terhadap usaha yang dijalankannya.

Laporan keuangan adalah catatan informasi keuangan atas kegiatan suatu perusahaan atau suatu lembaga unit lainnya pada suatu periode akuntansi yang dapat digunakan untuk menggambarkan kinerja perusahaaan atau lembaga unit lain tersebut
Kieso, Weygant dan Warfield (2007) menjelaskan komponen-komponen yang terdapat dalam laporan keuangan adalah sebagai berikut:

\section{a) Laporan Posisi Keuangan/Neraca (statement of financial position)}

Laporan Posisi Keuangan/Neraca adalah gambaran posisi keuangan perusahaan atau lembaga/organisasi pada suatu saat tertentu yang terdiri dri tiga unsur, yaitu aset, liabilitas dan ekuitas.

\section{b) Laporan Laba Rugi / Laporan Hasil Operasional / Laporan Sisa Hasil Usaha (Profit and loss statement)}

Laporan laba rugi atau laporan Sisa Hasil Usaha (SHU) merupakan suatu laporan sistematis tentang penghasilan, beban, laba maupun rugi yang diperoleh oleh suatu perusahaan selama periode tertentu. Laporan laba rugi membantu pemakai laporan keuangan mengevaluasi kemampuan perusahaan dalam beroperasi dan memprediksi hasil operasi perusahaan dimasa yang akan datang.

\section{c) Laporan Arus Kas}

Tujuan laporan arus kas adalah menyajikan informasi yang relevan mengenai penerimaan dan pengeluaran kas suatu perusahaan selama periode akuntansi tertentu. Informasi tentang arus kas suatu perusahaan akan berguna bagi para pemakai laporan keuangan sebagai dasar untuk menilai kemampuan perusahaan dalam menghasilkan kas dan setara kas dan menilai kebutuhan perusahaan untuk menggunakan arus kas, termasuk keputusan atas kebijakan direksi terhadap para pemilik modal (Kieso, Weygant \& Warfield, 2007:212).

\section{d) Laporan Perubahan Ekuitas}

Laporan perubahan ekuitas merupakan laporan yang merangkum perubahan-perubahan yang terjadi pada ekuitas pemilik selama satu periode waktu tertentu (Kieso, Weygant \& Warfield, 2007:31).

\section{e) Catatan Atas Laporan Keuangan}

Dalam PSAK Nomor 1 paragraf 70 disebutkan bahwa catatan atas laporan keuangan meliputi penjelasan naratif atau rincian jumlah yang tertera dalam Laporan Posisi Keuangan, Laporan LabaRugi, Laporan Arus Kas dan Laporan Perubahan Ekuitas serta informasi tambahan seperti kewajiban kontijensi dan komitmen. Catatan atas laporan keuangan juga mencakup informasi yang diharuskan dan dianjurkan untuk diungkapkan dalam Pernyataan Standar Akuntansi Keuangan serta pengungkapanpengungkapan lain yang diperlukan untuk 
menghasilkan penyajian laporan keuangan secara wajar

\section{Standar Akuntansi Keuangan (SAK)}

Entitas Tanpa Akuntabilitas Publik (SAK-ETAP) adalah Entitas yang.

a) Tidak memiliki akuntabilitas publik signifikan: dan

b) Menerbitkan laporan keuangan untuk tujuan umum (general purpose financial statement) bagi pengguna ekternal.

Entitas memiliki akuntabilitas publik signifikan:

1) Entitas telah mengajukan pernyataan pendaftaran, atau dalam proses pengajuan pernyataan pendaftaran, pada otoritas pasar modal atau regulator lain untuk tujuan penerbitan efek di pasar modal;

2) atau entitas menguasai aset dalam kapasitas sebagai fidusia untuk sekelompok besar masyarakat, seperti bank, entitas asuransi, pialang dan atau pedagang efek, dana pensiun, reksa dana dan bank investasi.

\section{Konsep dan Prinsip Pervasif}

Tujuan Laporan Keuangan adalah menyediakan informasi posisi keuangan, kinerja keuangan, dan laporan arus kas suatu entitas yang bermanfaat bagi sejumlah besar pengguna dalam pengambilan keputusan ekonomi oleh siapapun yang tidak dalam posisi dapat meminta laporan keuangan khusus untuk memenuhi kebutuhan informasi tertentu. Dalam memenuhi tujuannya, laporan keuangan juga menunjukkan apa yang telah dilakukan manajemen (stewardship) ataupertanggungjawaban manajemen atas sumber daya yang dipercayakan kepadanya.

Secara garis besar tujuan atas laporan keuangan adalah:

- Memberikan infomasi yang menyangkut posisi keuangan,kinerja sertaperubahan posisi keuangan suatuperusahaan yang bermanfaat bagi sejumlah besarpemakai dalam pengambilan keputusan ekonomi

- Laporan keuangan menunjukkan apa yang telah dilakukanmanajemen (stewardship), dan pertanggung jawabansumber daya yang dipercayakan kepadanya

- Memenuhi kebutuhan bersama sebagian besar pemakai.

- Menyediakan pengaruh keuangan dari kejadian di masalalu dan tidak diwajibkan menyediakan informasi nonkeuangan.
Penyajian Laporan Keuangan menurut SAK-ETAP dan Peraturan Menteri K-UKM No 12 Tahun 2015

\section{Neraca}

Neraca/Laporan Posisi Keuangan minimal mencakup pos-pos sebagai berikut:
a) Kas dan Setara Kas;
b) Piutang usaha dan Piutang lainnya;
c) Persediaan;
d) Properti Investasi;
e) Aset Tetap;
f) Aset Tidak Berwujud;
g) Utang Usaha dan Utang Lainnya;
h) Utang PPh dan Kewajiban pajak;
i) Kewajiban Diestimasi;
j) Ekuitas.

\section{Perhitungan Hasil Usaha}

Pendapatan adalah penghasilan yang timbul dalam pelaksanaan aktivitas entitas yang biasa dan dikenal dengan sebutan yang berbeda seperti penjualan, imbalan, bunga, royalty dan pendapatan sewa.
a) Pendapatan dari Pelayanan Anggota
b) Pendapatan dari Pelayanan Non-Anggota
c) Harga Pokok Penjualan
d) Sisa Hasil Usaha Kotor
e) Beban Operasional
a. Beban Administrasi dan Umum,
b. Beban Perkoperasian
c. Beban Usaha,
f) Pendapatan dan atau Beban Lainnya.
g) Beban Pajak Badan
h) Sisa Hasil Usaha Setelah Pajak

\section{Laporan Perubahan Ekuitas}

Laporan perubahan ekuitas bertujuan menyajikan laba/rugi koperasi untuk suatu periode, pos pendapatan dan beban yang diakui secara langsung dalam ekuitas untuk periode tersebut, pengaruh kebijakan akuntansi dan koreksi kesalahan yang diakui dalam periode tersebut. Informasi yang disajikan di laporan perubahan ekuitas meliputi:

a) Sisa hasil usaha untuk periode;

b) Pendapatan dan beban yang diakui langsung dalam ekuitas;

c) Pengaruh perubahan akuntansi dan koreksi kesalahan yang diakui, sesuai kebijakan akuntansi, estimasi, dan kesalahan untuk setiap komponen ekuitas;

d) Rekonsiliasi antara jumlah yang tercatat pada awal dan akhir periode untuk setiap komponen ekuitas, yang menunjukkan perubahan secara terpisah dari: 1. Sisa hasil usaha; 2. Pendapatan dan beban yang diakui langsung dalam ekuitas; 3. Jumlah SHU yang dibagikan dan distribusi lain untuk anggota, yang 
menunjukkan secara terpisah komponen simpanan anggota.

Adapun komponen-komponen Laporan Perubahan Ekuitas akan menunjukkan perubahan dari simpanan pokok, simpanan wajib, hibah, cadangan, sisa hasil usaha yang tidak dibagikan pada periode akuntansi.

\section{Laporan Arus Kas}

Laporan arus kas adalah laporan tentang arus masuk dan arus keluar uang tunai atau setara tunai. Laporan arus kas menyediakan informasi tentang perubahan uang tunai dan setara tunai dalam satu entitas untuk periode yang dilaporkan dalam komponen yang terpisah. Laporan arus kas terdiri dari:

a) Aktivitas Operasi, arus kas yang berasal dari aktivitas utama koperasi. Arus kas tersebut pada umumnya berasal dari transaksi dan peristiwa serta kondisi lain yang mempengaruhi besaran SHU

b) Aktivitas Investasi , arus kas penerimaan dan pengeluaran sehubungan dari sumber daya yang digunakan untuk tujuan menghasilkan pendapatan masa depan

c) Aktivitas Pendanaan, arus kas penerimaan dan pengeluaran yang berhubungan dengan sumber pendanaanuntuk tujuan menghasilkan pendapatan masa depan.

\section{Catatan Atas Laporan Keuangan}

Catatan atas laporan keuangan koperasi harus memuat pengungkapan kebijakan koperasi yangmengakibatkan perubahan perlakuan akuntansi dan pengungkapan informasi lainnya. Perlakuan akuntansi yangharus diungkapkan atau diinformasikan antara lain :

a) Gambaran Umum Koperasi

b) Informasi tentang dasar penyusunan laporan keuangan

c) Kebijakan akuntansi tentang pengakuan, pengukuran dan perlakuan: transaksi dalam mata uang asing, kas dan setara kas, piutang, penilaian persediaan, biaya dibayar dimuka, aset tetap, pajak penghasilan, dan sebagainya, diantaranya

1. Kebijakan akuntansi mengenai piutang

2. Kebijakan akuntansi tentang persediaan

3. Pengakuan, perlakuan dan kebijakan akuntansi mengenai aset tetap

d) Penjelasan yang mendukung pos-pos dan perhitungan sisa hasil usaha yang nilainya material (berdasarkan ketentuan pada masing-masing koperasi) sesuai dengan urutan penyajian setiap komponen laporan keuangan dan urutan penyajian pos-pos tersebut.

e) Catatan atas laporan keuangan koperasi harus jelas dan nyata, memuat informasi lain seperti :
1. Kegiatan usaha utama koperasi

2. Kegiatan pelayanan koperasi kepada anggota

3. Kegiatan bisnis koperasi dengan non anggota yang ditargetkan dan yang sudah dilaksanakan.

4. Informasi mengenai kegiatan bisnis koperasi dengan non anggota yang ditargetkan dan yang sudah dilaksanakan.

5. Aktivitas koperasi untuk mempromosikan ekonomi dan pengembangan kemampuan sumberdaya anggota melalui pendidikan dan pelatihan.

\section{Penelitian Terdahulu}

Sebagai bahan perbandingan dalam penelitan Analisis Penerapan Standar Akuntansi Keuangan Entitas Tanpa Akuntabilitas Publik Dalam Penyajian Laporan Keuangan, diantaranya penelitian yang dilakukan oleh para peneliti terdahulu yang peneliti tampilkan dalam tabel 1 atas rangkuman hasil penelitian terdahulu sebagai berikut:

Tabel 1.

\section{Rangkuman hasil Penelitian Terdahulu}

\begin{tabular}{|c|c|c|c|c|}
\hline No & $\begin{array}{c}\text { Nam } \\
\text { a } \\
\text { Penel } \\
\text { iti } \\
\text { dan } \\
\text { Tahu } \\
\text { n } \\
\text { Penel } \\
\text { itian }\end{array}$ & $\begin{array}{c}\text { Judul } \\
\text { Penelitia } \\
\mathrm{n}\end{array}$ & $\begin{array}{c}\text { Variab } \\
\text { el dan } \\
\text { Alat } \\
\text { Analis } \\
\text { is }\end{array}$ & Hasil Penelitian \\
\hline 1 & $\begin{array}{l}\text { Yulia } \\
\text { na } \\
\text { Sapu } \\
\text { tri } \\
\text { (201 } \\
6)\end{array}$ & $\begin{array}{l}\text { Penerap } \\
\text { an } \\
\text { Standar } \\
\text { Akuntan } \\
\text { si } \\
\text { Keuang } \\
\text { an } \\
\text { Entitas } \\
\text { Tanpa } \\
\text { Akuntab } \\
\text { ilitas } \\
\text { Publik } \\
\text { (SAK } \\
\text { ETAP) } \\
\text { Pada } \\
\text { Lapran } \\
\text { Laporan } \\
\text { Keuang } \\
\text { an } \\
\text { Koperas } \\
\text { i } \\
\text { Sejahter } \\
\text { a }\end{array}$ & $\begin{array}{l}\text { Penelit } \\
\text { ian ini } \\
\text { melalu } \\
\text { i } \\
\text { observ } \\
\text { asi, } \\
\text { wawan } \\
\text { cara } \\
\text { dan } \\
\text { studi } \\
\text { kepust } \\
\text { akaan }\end{array}$ & $\begin{array}{lr}\text { penyajian } & \text { laporan } \\
\text { keuangan } & \text { koperasi } \\
\text { Sejahtera } & \text { Pontianak } \\
\text { belum menerapkan } & \text { Standar Akuntansi } \\
\text { Keuangan } & \text { Entitas } \\
\text { Tanpa Akuntabilitas } \\
\text { Publik (SAK-ETAP). } \\
\text { Laporan Keuangan } \\
\text { Koperasi Sejahtera } \\
\text { Pontianak terdiri atas } \\
\text { Neraca, laporan sisa } \\
\text { hasil usaha dan arus } \\
\text { kas. }\end{array}$ \\
\hline
\end{tabular}




\begin{tabular}{|c|c|c|c|c|}
\hline & & $\begin{array}{l}\text { Pontiana } \\
\mathrm{k}\end{array}$ & & \\
\hline 2 & $\begin{array}{l}\text { R. } \\
\text { Taufi } \\
\text { k } \\
\text { Hida } \\
\text { yat, } \\
\text { SE., } \\
\text { MM } \\
\text { Si } \\
(201 \\
6)\end{array}$ & $\begin{array}{l}\text { Penerap } \\
\text { an SAK- } \\
\text { ETAP } \\
\text { (Standar } \\
\text { Akuntan } \\
\text { si } \\
\text { Keuang } \\
\text { an } \\
\text { Entitas } \\
\text { Tanpa } \\
\text { Akuntab } \\
\text { ilitas } \\
\text { Publik) } \\
\text { Untuk } \\
\text { Pelpora } \\
\text { n } \\
\text { Keuang } \\
\text { an Bagi } \\
\text { Entitas } \\
\text { Usaha } \\
\text { Koperas } \\
\text { i dan } \\
\text { Usaha } \\
\text { Mikro } \\
\text { Kecil } \\
\text { Meneng } \\
\text { ah Di } \\
\text { Indonesi } \\
\text { a. }\end{array}$ & $\begin{array}{l}\text { Penelit } \\
\text { ian ini } \\
\text { melalu } \\
\text { i } \\
\text { observ } \\
\text { asi, } \\
\text { wawan } \\
\text { cara } \\
\text { dan } \\
\text { studi } \\
\text { kepust } \\
\text { akaan }\end{array}$ & $\begin{array}{lr}\text { SAK-ETAP } \\
\text { disiapkan } \\
\text { Small interprises } \\
\text { (Usaha } \\
\text { menengah) karena } \\
\text { dianggap } \\
\text { transaksinya lebih } \\
\text { sederhana dan tidak } \\
\text { perlu melaporkan } \\
\text { melaporkan laporan } \\
\text { keuangan kepada } \\
\text { publik/masyarakat } \\
\text { secara luas. }\end{array}$ \\
\hline 3 & $\begin{array}{l}\text { Eni } \\
\text { Mina } \\
\text { rni, } \\
\text { Krisa } \\
\text { n } \\
\text { Sisdi } \\
\text { yanto } \\
\text { ro } \\
\text { (201 } \\
\text { 4) }\end{array}$ & $\begin{array}{l}\text { Faktor- } \\
\text { Faktor } \\
\text { Yang } \\
\text { Mempe } \\
\text { ngaruhi } \\
\text { Impele } \\
\text { mentasi } \\
\text { Standar } \\
\text { Akuntan } \\
\text { si } \\
\text { Keuang } \\
\text { an } \\
\text { Entitas } \\
\text { Tanpa } \\
\text { Akuntab } \\
\text { ilitas } \\
\text { Publik } \\
\text { (studi } \\
\text { empiris } \\
\text { pada } \\
\text { Koperas } \\
\text { i di } \\
\text { Tulung } \\
\text { Agung) }\end{array}$ & $\begin{array}{l}\text { penelit } \\
\text { ian ini } \\
\text { melalu } \\
\text { i } \\
\text { observ } \\
\text { asi, } \\
\text { wawan } \\
\text { cara } \\
\text { dan } \\
\text { studi } \\
\text { kepust } \\
\text { akaan. }\end{array}$ & $\begin{array}{l}\text { Komitmen dan } \\
\text { pemanfaatan } \\
\text { tehnologi informasi } \\
\text { terhadap SAK-ETAP } \\
\text { di Tulung Agung, } \\
\text { dengan hasil yang } \\
\text { signifikan. }\end{array}$ \\
\hline
\end{tabular}

\begin{tabular}{|c|c|c|c|c|}
\hline 4 & $\begin{array}{l}\text { Fara } \\
\text { h } \\
\text { Lydi } \\
\text { a Eka } \\
\text { Rini } \\
(201 \\
4)\end{array}$ & $\begin{array}{l}\text { Penyusun } \\
\mathrm{n} \\
\text { Penyajian } \\
\text { Laporan } \\
\text { Keuangan } \\
\text { berbasis } \\
\text { SAK- } \\
\text { ETAP } \\
\text { (studi pad } \\
\text { UMKM } \\
\text { ekspedisi } \\
\text { CV. } \\
\text { Mandiri) } \\
\text { Kota } \\
\text { Pontianak }\end{array}$ & $\begin{array}{l}\text { penelit } \\
\text { ian ini } \\
\text { melalu } \\
\text { i } \\
\text { observ } \\
\text { asi, } \\
\text { wawan } \\
\text { cara } \\
\text { dan } \\
\text { studi } \\
\text { kepust } \\
\text { akaan. }\end{array}$ & 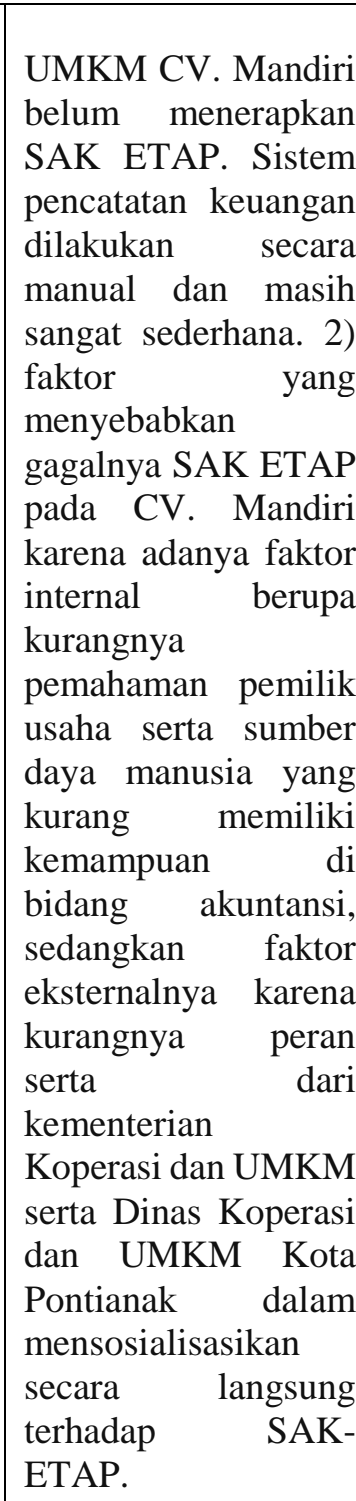 \\
\hline 5 & $\begin{array}{l}\text { Erma } \\
\text { Sury } \\
\text { anti, } \\
\text { Iriani } \\
\text { ng } \\
\text { Supa } \\
\text { rlina } \\
\text { h, I } \\
\text { Way } \\
\text { an } \\
\text { Must } \\
\text { ika } \\
\text { (201 } \\
\text { 4) }\end{array}$ & $\begin{array}{l}\text { Penerap } \\
\text { an } \\
\text { Standar } \\
\text { Keuang } \\
\text { an Tapa } \\
\text { Akuntab } \\
\text { ilitas } \\
\text { Publik } \\
\text { (SAK- } \\
\text { ETAP) } \\
\text { pada } \\
\text { Koperas } \\
\text { i Eks } \\
\text { Karesid } \\
\text { enan } \\
\text { Banyum } \\
\text { as }\end{array}$ & & 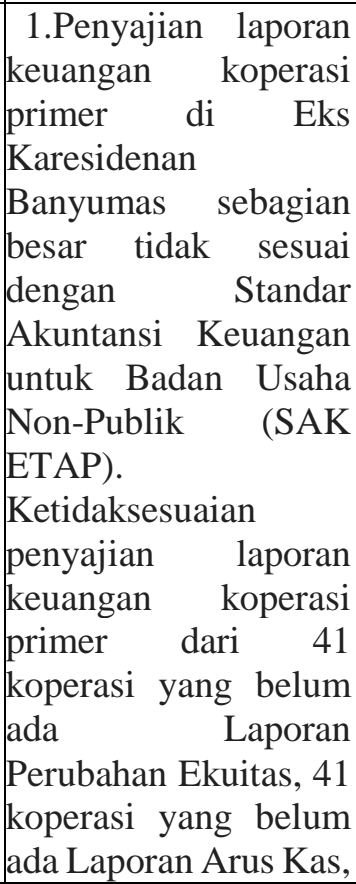 \\
\hline
\end{tabular}




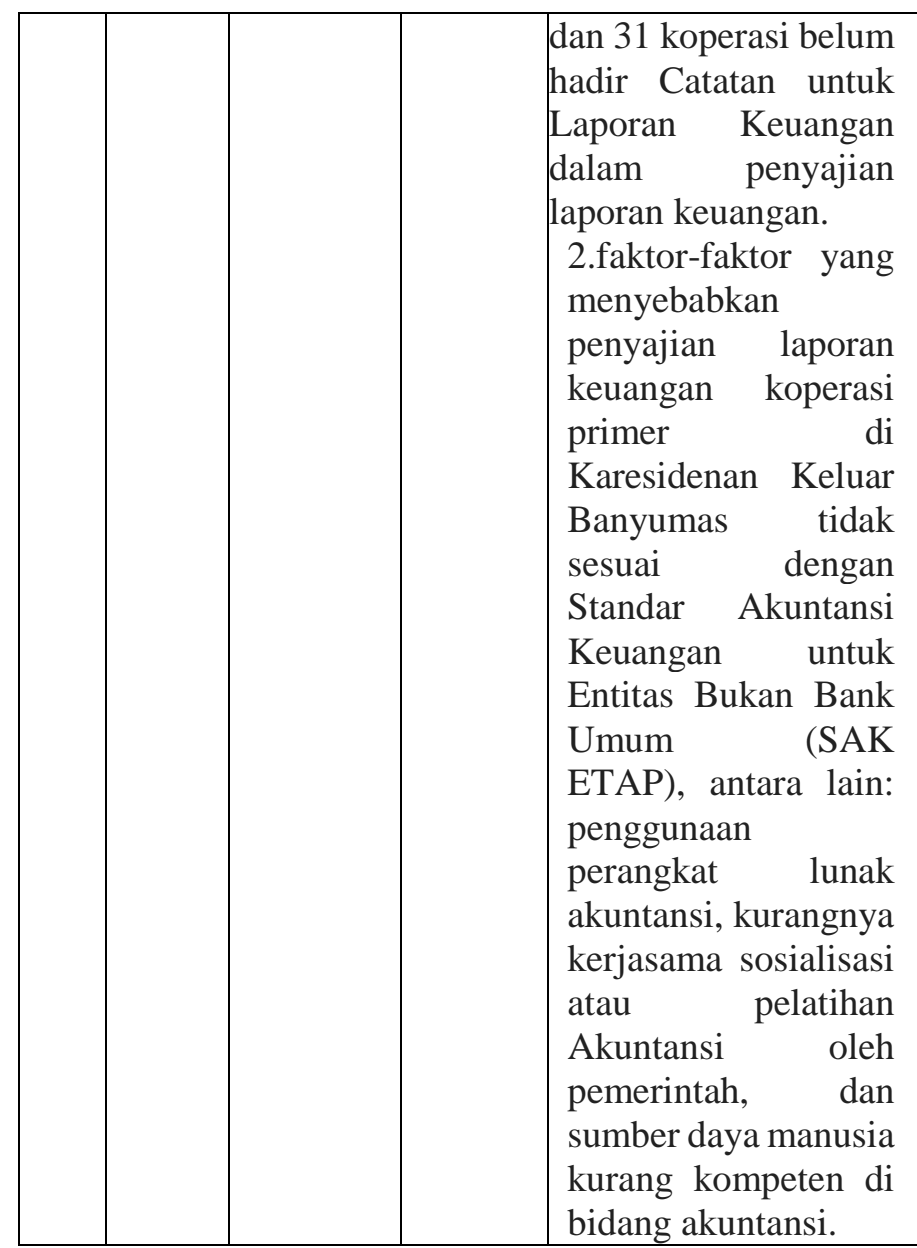

\section{Kerangka Berfikir Teoritis}

Kerangka berfikir teoritis dalam penelitian ini adalah SAK-ETAP merupakan variabel bebas (independent) dan Laporan Keuangan KPRI "Manfaat" LPMP Ja-teng merupakan variabel terikat (dependent) dari kedua variabel tersebut di bandingkan dan dievaluasi.

Model hubungan antara varibel dependen dan variabel independen tersebut dapat dilihat pada gambar 2.1. berikut ini.

GAMBAR 2.1

\section{KERANGKA BERFIKIR TEORITIS}

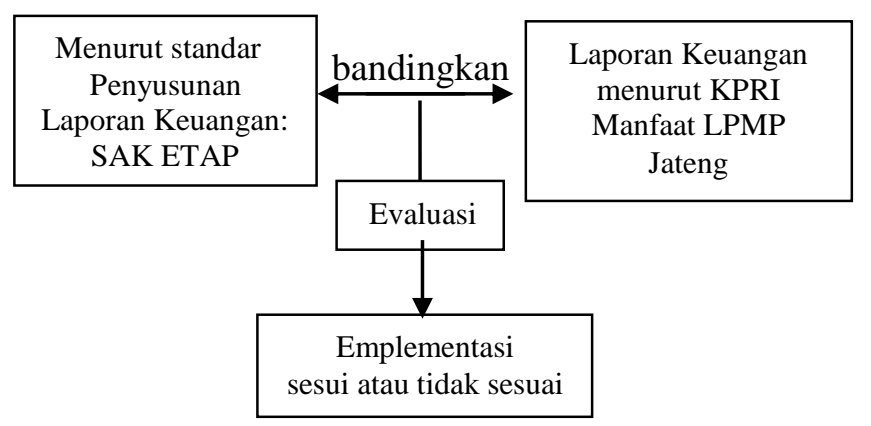

2. Hipotesis

Standar Akuntansi Keuangan Entitas Tanpa Akuntabilitas Publik merupakan pedoman yang diundangkan oleh Departemen Koperasi dan UKM melalui Peraturan Menteri Negara Koperasi dan UKM dengan No. 12/Per/M.KUKM/IX/2015 Tentang Pedoman Umum Akuntansi Koperasi Sektor Riil.

Dalam pasal 3 ayat 1 menyebutkan, Koperasi sektor riil yang tidak memiliki akuntabilitas publik, maka dipersyaratkan laporan keuangannya mengacu kepada Standar Akuntansi Keuangan Entitas Tanpa Akuntabilitas Publik (SAK-ETAP)..

Berdasarkan konseptual tersebut diatas hipotesis yang akan diuji dalam penelitian ini adalah:

H1 : Apakah Koperasi Pegawai Republik Indonesia (KPRI) "Manfaat" LPMP Jawa Tengah sudah menerapkan akuntansi keuangann atau sudah menyesuaikan Standar Akuntansi Keuangan Entitas Tanpa Akuntabilitas Publik ?

H2: Apakah Standar Akuntansi Keuangan Entitas Tanpa Akuntabilitas Publik (SAK-ETAP) berpengaruh terhadap Penyajian Laporan Keuangan KPRI "Manfaat" LPMP Jawa Tengah?

H3: Faktor - faktor apakah yang mempengaruhi Standar Akuntansi Keuangan Entitas Tanpa Akuntabilitas Publik (SAK-ETAP) terhadap Penyajian Laporan Keuangan KPRI "Manfaat" :PMP Jawa Tengah?

Gambar: 1.

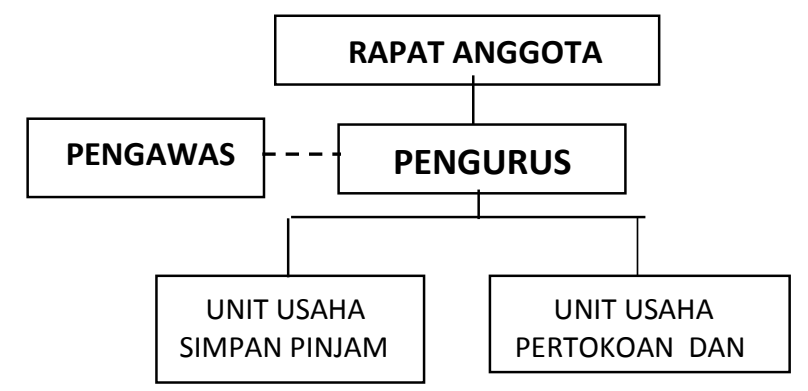

Sumber data: KPRI "Manfaat

\section{Pembahasan}

\section{Penyajian Laporan Keuangan KPRI "Manfaat LPMP Jawa Tengah}

\section{A. Neraca}

Neraca KPRI "Manfaat LPMP Jawa Tengah dalam penyajian pos aset lancar, belum sesuai dengan klasifikasi SAK ETAP karena adanya Kas Toko dan Kas Simpan Pinjam yang seharusnya kedua akun tersebut merupakan sub akun dari "Kas dan Setara Kas" selain itu harus di tampakkan saldo sub akun "Kas Kecil" untuk pembayaran beban-beban operasional. Untuk penyajian 
terhadap Ativa Tetap sudah sesuai dengan yang ditetapkan oleh SAK ETAP hanya saja perlu adanya penjelasan terhadap nilai penyusutan dan penggunaan metode penyusutan yang disajikan dalam Catatan Atas Laporan Keuangan.

1. Klasifikasi hutang jangka pendek dan hutang jangka panjang.

KPRI "Manfaat" telah menyajikan pos kewajiban lancar sesuai dengan klasifikasikan kewajiban lancar yang diatur dalam SAK ETAP dimana kewajiban lancar tersebut akan diselesaikan dalam jangka waktu paling lambat 12 bulan setelah akhir periode pelaporan. Perlu diperhatikan bahwa koperasi ini sudah melakukan perhitungan terhadap "Beban Pajak" dalam laporan Laba rugi, maka perlu dimunculkan akun Hutang Pajak PPh" dalam kelompok Kewajiban Lancar sebesar nilai beban pajak yang diperhitugkan sebelum pembayaran pajak penghasilan $(\mathrm{PPh})$.

\section{B. Laporan Sisa Hasil Usaha}

Dalam penyajian laporan laba rugi KPPR "Manfaat" LPMP Jawa Tengah belum sesuai dengan SAK ETAP yang bertujuan untuk memahami kinerja keuangan dan juga entitas menyajikan atau mengungkapkan pos pendapatan dan beban, dalam laporan Sisa Hasil Usaha. Akun beban pajak juga terdapat dalam laporan laba rugi yang menunjukkan bahwa KPRI “ Manfaat" sudah memenuhi kewajiban membayar pajak sebagaimana yang telah diwajibkan dalam SAK ETAP. Namun perlu ditinjau kembali alenia no 2 dalam laporan Laba Rugi KPRI "Manfaat" tersebut diatas menampilkan "Unit Simpan Pinjam" yang seharusnya masuk dalam penjelasan terhadap Piutang Simpan Pinjam dalam Catatan Atas Laporan Keuangan.

\section{Laporan Arus Kas}

Entitas menyajikan laporan arus kas yang melaporkan arus kas untuk suatu periode dan mengklasifikasikan menurut aktivitas operasi, aktivitas investasi, dan aktivitas pendanaan, dan KPPR "Manfaat" tidak menyajikan Laporan Arus Kas yang diamanatkan oleh SAK-ETAP dan Peraturan Menteri K-UKM No 12 Tahun 2015

\section{Laporan Perubahan Ekuitas \\ KPRI "Manfaat" LPMP Jawa Tengah tidak menyajikan laporan perubahan ekuitas selama periode usahanya}

\section{E. Catatan Atas Laporan Keuangan}

Catatan atas laporan keuangan disajikan secara sistematis sepanjang hal tersebut praktis. Setiap pos dalam laporan keuangan merujuk-silang ke informasi terkait dalam catatan atas laporan keuangan. KPRI "Manfaat" LPMP Jawa Tengan tidak membuat catatan atas laporan keuangan yang menyebabkan kurangnya informasi dalam memahami keberadaan posisi keuangannya. Hal tersebut tidak sesuai dengan SAK ETAP yang mewajibkan setiap ETAP untuk membuat catatan atas laporan keuangan.

\section{Laporan Keuangan Berdasarkan SAK ETAP}

Dari paparan di atas, terdapat ketidak sesuaian laporan keuangan yang disajikan KPRI "Manfaat" ditinjau berdasarkan SAK ETAP, yaitu sebagai berikut:

a. Tidak adanya akun cadangan penyisihan piutang tak tertagih yang seharusnya disajikan untuk menghapus piutang khusus pada neraca dan akun piutang khusus tersebut pada neraca seharusnya disajikan terpisah dari dari pos aktiva lancar dan disajikan pada pos aktiva lain-lain.

b. Nilai penyusutan yang terseji pada neraca melebihi nilai perolehan aset dan harus disesuaikan.

c. Kewajiban membayar pajak yang belum diterapkan.

d. Penyajian gedung yang disajikan pada pos aktiva tetap yang pada kenyataannya gedung tersebut bukan hak milik koperasi dan seharusnya koperasi melakukan pembayaran sewa atas gedung yang ditempati tersebut

e. Tidak adanya laporan perubahan ekuitas dan catatan atas laporan keuangan.

\section{Apakah Koperasi Pegawai Republik Indonesia (KPRI) "Manfaat" LPMP Jawa Tengah sudah menerapkan akuntansi keuangann atau sudah menyesuaikan Standar Akuntansi Keuangan Entitas Tanpa Akuntabilitas Publik ?}

Sesuai dengan SAK ETAP yang termaktub dalam Pedoman Umum Akuntansi Koperasi dalam Peraturan Menteri Negara Dan Usaha Kecil dan Menengah Republik Indonesia NOMOR 04/Per/M.KUKM/VII/2012 sangat perlu diterapkan dengan baik karena bertujuan: menyediakan pedoman yang standar tentang penyajian laporan keuangan koperasi, sehingga membantu mempercepat pengurus dalam menyusun laporan pertanggungjawaban keuangan koperasi pada rapat anggota tahunan, maupun untuk tujuan-tujuan lain.

Pada umumnya KPRI "Manfaat" LPMP Jawa Tengah sudah menjalankan pencatatan pembukuaan akuntansi sehari hari dengan secara kronologis dan penataan format yang baik dan setiap terjadi transaksi keuangan selalu dicatat tepat pada waktunya. Namun 
Laporan Keuangan yang disajikan dalam pelaporan tahunan Rapat Anggota Tahunan (RAT) belum menerapkan atau belum menyesuaikan terhadap standar akuntansi keuangan entitas tanpa akuntabilitas publik (SAK-ETAP),

\section{Apakah Standar Akuntansi Keuangan Entitas Tanpa Akuntabilitas Publik (SAK-ETAP) berpengaruh terhadap Penyajian Laporan Keuangan Koperasi?}

Penyajiak laporan keuangan yang disajikan dalam RAT yang berdasar pada standar akuntansi keuangan entitas tanpa akuntabilitas (SAK-ETAP) berpengaruh terhadap penyajian laporan keuangan koperasi, hal ini karena:

1. Secara umum pengguna laporan keuangan koperasi yaitu para anggota koperasi enggan bahkan menerima laporan dengan baik tanpa adanya kendala bagi peserta RAT dan pada umumnya menerima laporan apa adanya walaupun penyajian laporan keuangan tidak sesuai dengan yang di anjurkan tentang SAKETAP yang termaktub dalam Pedoman Umum Akuntansi Koperasi oleh Menteri Koperasi Dan Usaha Kecil dan Menengah Repubik Indonesia NOMOR 04/Per/M.KUKM/ VII/2012.

2. Kurangnya pengetahuan atas teknologi informasi akuntansi dan manajemen keuangan yang disebabkan oleh minimnya kesempatan untuk mengikuti perkembangan teknologi serta kurangnya pendidikan dan pelatihan

3. Keterbatasan sumber daya manusia serta kurangnya sumber daya untuk mengembangkan perkoperasian

4. Kurangnya pemahaman mengenai keuangan dan akuntansi yang disebabkan minimnya dan terbatasnya pengetahuan tentang akuntansi dan keuangan.

Faktor - faktor apakah yang mempengaruhi Standar Akuntansi Keuangan Entitas Tanpa Akuntabilitas Publik (SAK-ETAP) terhadap Penyajian Laporan Keuangan Koperasi

Faktor-faktor yang mempengaruhi standar akuntansi keuangan entitas tanpa akuntabilitas publik (SAK-ETAP) adalah:

1. Sumber daya manusia yang dimiliki lembaga koperasi Pegawai Repulik Indonesia (KPRI) "Manfaat" LPMP Jawa Tengah relatif kurang memiliki kemampuan di bidang akuntansi. Fakta di lapangan menunjukkan bahwa pengurus lembaga belum mengetahui keberadaan SAK ETAP yang dirancang khusus untuk entitas tanpa akuntabilitas publik dan walaupun mengetahui yang diundangkan oleh Menteri Koperasi dan
Usaha Kecil dan Menengah RI NOMOR 04/Per/M.KUKM/VII/2012 dan pelatihan sudah dijalankan dengan baik. Sedangkan karyawan bagian administrasi cukup mengerti mengenai dasar-dasar akuntansi, akan tetapi untuk pengetahuan yang lebih rinci tentang penyusunan laporan keuangan yang sesuai dengan SAK ETAP, masih kurang.

2. Kurangnya kesadaran dan disiplin dari pihak lembaga koperasi akan pentingnya laporan keuangan yang lengkap dan sesuai standar. Pihak perusahaan merasa bahwa laporan keuangan yang menunjukkan laba rugi perusahaan saja sudah cukup.

3. Kurangnya peran serta dan kurang efektifitas dari Dinas Koperasi dan UMKM Kota Semarang dalam mensosialisaikan serta melakukan pelatihan kepada pelaku usaha perkoperasian agar dapat memahami dan mengimplementasikan Standar Akuntansi Keuangan untuk Entitas Tanpa Akuntabilitas Publik (SAK ETAP) terhadap usaha yang dijalankannya.

4. Banyaknya kegiatan-kegiatan para pengelola lembaga koperasi diluar kegiatan pengelolaan koperasi serta manajemen koperasi yang tidak bisa berdiri sendiri yang masih mengikuti kebijakankebijakan dari pimpinan instasi terkait.

\section{A. PENUTUP}

1. Kesimpulan

Tujuan penelitian ini adalah untuk memperoleh bukti empiris mengenai Penerapan Standar Akuntansi Keuangan Entitas Tanpa Akuntabilitas Publik dalam Penyajian Laporan Keuangan pada KPRI "Manfaat" LPMP Jawa Tengah

Dari hasil penelitan ini, maka dapat disimpulkan bahwa:

a. Laporan Keuangan yang disajian belum menerapkan sesuai dengan SAK-ETAP yang dipedomkan dalam Peraturan Menteri Koperasi dan Usaha Kecil dan Menengah Republik Indonesia NOMOR 04/Per/M.KUKM/VII/2012

b. Laporan keuangan yang dibuat oleh pegawai KPRI "Manfaat" LPMP Jawa Tengah masih belum sesuai dengan SAK-ETAP yang dipedomkan dalam Peraturan Menteri Koperasi dan Usaha Kecil dan Menengah Republik Indonesia NOMOR 04/Per/M.KUKM/VII/2012 . penyajian Laporan Keuangan masih sederhana dan terbatas pada Neraca dan Laporan Rugi Laba terklasifikasi. 
c. Pengelola Koperasi masih bersamaan atau merangkap jabatan pada pegawai di lembaga atau instansi dalam naungan Instansi yang bersangkutan, sehingga dalam memfokuskan pengelolaan koperasi masih terabaikan.

d. Badan usaha KPRI "Manfaat" LPMK Jawa Tengah masih memerlukan pembinaan tentang pembuatan laporan keuangan yang berdasaran SAK-ETAP..

2. Keterbatasan Penelitian

Penelitian ini masih memiliki beberapa keterbatan baik dalam pemilihan sampel maupun hasil pengujian. Keterbatasan penelitian ini adalah sebagai berikut :

Bahwa peneliti hanya terbatas pada penelitan pada perbandingan Laporan Keuangan yang disajikan oleh KPRI "Manfaat" LPMK Jawa Tengah dengan SAKETAP yang dipedomkan dalam Peraturan Menteri Koperasi dan Usaha Kecil dan Menengah Republik Indonesia NOMOR 04/Per/M.KUKM/VII/2012

3. Saran

Dengan melihat hasil penelitian dan keterbatan penelitan yang disebut diatas, maka saran yang dapat disampaikan pada peneliti berikutnya adalah sebagai berikut

1. Penelitian selanjutnya diharapkan untuk melakukan penelitian yang lebih mendalam, sehingga diharapkan dapat memperoleh hasil yang lebih komprehensif dan lebih efektif dari penelitian yang telah peneliti dilakukan.

2. Penelitian selanjutnya diharapkan dapat menambah variabel-variabel penelitian yang lain sehingga dapat memperluas jangkauan penelitian.

3. Penelitian selanjutnya diharapkan dapat menggunakan alat analisis yang lebih baik dibanding dengan penelitian sebelumnya.

\section{DAFTAR PUSTAKA}

Donald E. Kieso, Jerry J. Weygandt, \& Terry D. Warfield.2008. Akuntansi Intermediate. Jakarta: Erlangga.

Lexy J. Moleong, 2009, Metodologi Penelitian Kualitatif. Bandung: PT. Remaja Rosdakarya.

Ikatan Akuntan Indonesia. 2013, Entitas Tanpa Akuntabilitas Publik, Penerbit Ikatan Akuntan Indonesia. Jakarta.

Ikatan Akuntan Indonesia. 2011, Buletin Teknis 6. Keterterapan SAK ETAP Untuk Entitas Koperasi danEntitas Nirlaba, Penerbit Ikatan Akuntan Indonesia. Jakarta.

Peraturan Menteri Koperasi san Usaha Kecil dan Menengah Republik Indonesia No 12/Per/M.KUKM/IX/2015 Tentang Pedoman
Umun Akuntansi Koperasi Sektor Riil, diakses tanggal 23 Oktober 2018

Koperasi.net, 2012, Manajemen Koperasi Indonesia (http://www.koperasi.net/ diakses tanggal 3 Desember 2017).

Martani, Dwi, 2011, Standar Akuntansi Keuangan Entitas Tanpa Akuntabilitas Publik (SAK ETAP,(http://staff.blog.ui.ac.id/martani/files/201 1/03/Standar-Akuntansi-Keuangan-Entitas-

Tanpa-Akuntanbilitas-Publik-SAK-ETAP.pdf diakses tanggal 3024 Nopember 2017) 